\title{
Soil contamination and human health: part 2
}

\author{
Jaume Bech
}

Published online: 17 March 2020

(C) Springer Nature B.V. 2020

\section{Background}

This collection of papers submitted to this Special Issue is mainly an outcome of the Session SSS8.5, EGU2018 "Soil contamination and human health: advances and problems of risk assessment", the European Geosciences Union (EGU) Conference held in Vienna, April 2018.

Development of soil geochemistry and geochemical ecology has demonstrated a correlation between concentration of certain elements in soil, their transfer to local food chains and biological reactions to deficiency or excess of the particular elements, including diseases such as goitre, fluorosis, selenosis, cancer and others. The development of analytical chemistry combined with developing GIS increase in spatial correlation between soil geochemistry and medical data. It is necessary to establish the optimal level for population health and evaluate the spatial distribution of soil chemicals above or below these optimal levels.

This Special Issue contains 21 papers written by authors from 23 countries: Austria, Belarus, Chile, China, Germany, India, Iran, Italy, Korea, Lebanon, Mexico, Pakistan, Peru, Portugal, Russian Federation, Syria, Spain, Switzerland, Thailand, Turkey, UK, USA and Vietnam. This collection of papers is mainly

J. Bech $(\bowtie)$

Barcelona, Spain

e-mail: jaumebechborras@gmail.com focused on seven topics: (1) soil-plant interactions and phytoremediation, (2) water and river sediments, (3) PAHs, (4) biochar, (5) microbial activity, (6) urban soils and (7) endemic diseases. In the following paragraph, I will summarize the content and main results of these papers published in this Special Issue.

\section{Research topics}

Soil-plant interactions and phytoremediation

There are nine papers dealing with this first topic, soilplant interactions, phytoremediation:

Dbaibo et al. (2019) studied the levels of $\mathrm{Cd}, \mathrm{Pb}$ and $\mathrm{Ni}$ in Origanum syriacum produced in Lebanon. The study consist of three parts: (1) pot experiment to research the effect of different concentrations of $\mathrm{Cd}$, $\mathrm{Pb}$ and $\mathrm{Ni}$ in soil on their uptake by O. syriacum; (2) field samples collected from agricultural regions in Lebanon to check the levels of $\mathrm{Cd}, \mathrm{Pb}$ and $\mathrm{Ni}$ in soil and leaves; and (3) sale of outlet samples: to measure the levels of $\mathrm{Cd}, \mathrm{Pb}$ and $\mathrm{Ni}$ in O. syriacum tissues in the market. Results showed a positive correlation between levels of $\mathrm{Cd}, \mathrm{Pb}$ and $\mathrm{Ni}$ in soil and those in O. syriacum tissues. None of the Origanum samples collected from fields in Lebanon was high in $\mathrm{Cd}, \mathrm{Pb}$ and $\mathrm{Ni}$ but two mixture samples purchased from stores in Lebanon were higher than the maximum allowable WHO limits. 
Carvalho et al. (2019) evaluated the growth and the physiological response of Cistus salviifolius L. to high As concentration in an hydroponic system for 30 days. Growth, chlorophyll content, chemical composition, $\mathrm{H}_{2} \mathrm{O}_{2}$ indicator of oxidative stress and antioxidative metabolites such ascorbate and glutathione were analysed. Taking the values of chlorophylls into account, it is possible to infer that As did not interfere in the photosynthetic capacity of the plants. $C$. salviifolius showed high tolerance to As up to the concentration of $5 \mathrm{mg} \mathrm{L}^{-1}$, which makes it a species with high potential to be used in the phytostabilization of soils that contain high concentrations of As in the soil solution.

Pace et al. (2019) investigated $\mathrm{Pb}$ transfer into the vegetation layer (Phragmites australis, Salix alba and Sambucus nigra) growing along a $\mathrm{Pb}$ contaminate river bank site of Gualdo Tadino (Umbria, Italy). Salix was not affected by the $\mathrm{Pb}$ contamination. Sambucus accumulated high concentrations of $\mathrm{Pb}$ in all plant tissues and fruits, therefore representing a potential source for the biomagnification. Phragmites accumulated large amounts of $\mathrm{Pb}$ in the rhizomes, though it can be employed for the in situ stabilization of contaminated soils and it can reduce soil erosion, water runoff and the contamination of the surrounding environment.

Suwatvitayakorn et al. (2019) assessed the human health risk of $\mathrm{Cd}$ exposure through rice consumption in Cd-contaminated areas of Mae Tao sub-district, Tak, Thailand. One hundred fifty-nine rice samples were collected from households in all six villages and analysed for Cd by ICP-MS. The results showed that both locally grown rice and retail rice were contaminated with $\mathrm{Cd}$. The locally grown rice contained total $\mathrm{Cd}$ higher than that of the retail rice. The potential health risk (HQ) values of Cd exposure from only sticky rice consumption and both types of rice consumption were higher than the threshold value of $1(\mathrm{HQ}>1)$ indicating potential health impact in the local residents. Therefore, it is recommended that local residents should consume rice from the uncontaminated area, as well as reducing the amount of rice consumed.

Monaci et al. (2019) studied the phytostabilization capacity of Erica australis L. and Nerium oleander L. in the Riotinto mining area (SW Spain). The authors found that both species tolerate extreme acidic conditions, water-limited substrates, very poor in nutrients such $\mathrm{N}$ and $\mathrm{P}$ and highly enriched with phytotoxic elements (e.g. $\mathrm{Cu}, \mathrm{Cd}, \mathrm{Pb}, \mathrm{S}$ ), hence unstable habitats. The accumulation of toxic elements in the roots and not transfer of them to shoots, avoiding run the risk to consumers through the food chain. E. australis is the best candidate to promote primary phytostabilization of mineral substrates of tailings, dumps and other mine wastes and favour the establishment of less tolerant species such as $N$. oleander.

Armienta Hernandez et al. (2019) researched the potentially harmful elements (PHEs) assimilation in maize (Zea mays L.) plants growing near mine tailings of Hidalgo State, Mexico. The authors evaluated the concentrations of As and heavy metals in maize plants cultivated in a greenhouse in two soils influenced by tailings. Important concentrations of PHEs were recorded in grains, stalk and cob sheath. The order of accumulation was: $\mathrm{Zn}>\mathrm{Fe}>\mathrm{Pb}>\mathrm{As}>\mathrm{Cd}$. $\mathrm{Cd}$ was not detected in grains at a maximum of AS at $1.02 \mathrm{mg} / \mathrm{Kg}$, and $\mathrm{Pb}$ at $3.9 \mathrm{mg} / \mathrm{Kg}$ was found in the dry grain. These As and $\mathrm{Pb}$ concentrations do not comply with Codex Alimentarius-FAO standards for maize, and consumption represents a health risk to humans and animals.

Nguyen et al. (2019) investigated paddy soil geochemistry, uptake of trace elements by rice grains (Oryza sativa) and resulting health risks in the Mekong River Delta, Vietnam. Results show $11 \%$ of researched soils exceed the permissible As Vietnam limits and $\mathrm{Pb}$ and $\mathrm{Sb}$ surpass the background values in one soil sample. All other elements are far below their permissible soil limits. There is no clear correlation of trace element concentrations in soils with those in corresponding grains, except for $\mathrm{Mn}$. In relation to assessment of health risks of critical elements in rice, surprisingly, rice grown on non- or low-polluted soils can surpass the upper limits. The authors concluded that in some parts of lowland river areas in Vietnam, the intense continuous rice consumption may lead to chronic exposure to $\mathrm{As}, \mathrm{Cd}$ and $\mathrm{Pb}$ and potential health risks to the local population.

Praveen and Pandey (2019) offered a review of Pteridophytes that can be used in phytoremediation of contaminants from soil cleanup of metal-contaminated ecosystems. The authors described potential features of Pteridophytes and its strategic advantages in phytoremediation. Among the first of note are: having good biomass, requiring less growing time, being mostly perennials, most being not edible for 
humans and livestock. Strategic advantages are antioxidative defence (e.g. SOD, CAT, APX, etc.) that reduces toxicity, phosphate transporters, herbivory, sequestration of contaminants in vacuoles, chelating agents, active senescence and others. Also some microorganisms participate in rhizoremediation, and some genes such ACR3 are localized in membranes of vacuoles. The authors also reported a completed list of Pteridophytes: Pteris vittata (As), Nephrolepis cordifolia and Hypolepis muelleri $(\mathrm{Cu}$, $\mathrm{Pb}, \mathrm{Zn}, \mathrm{Ni}$ ), Adiantum (As, $\mathrm{Pb}, \mathrm{Ni}$ ), etc.

Antisari et al. (2019) studied the translocation of potentially toxic elements from soil to black cabbage (Brassica oleracea L.) growing in an abandoned mining district of Pietrasanta Municipality, Apuan Alps, Italy. The results indicate that mean concentrations of $\mathrm{As}, \mathrm{Cu}, \mathrm{Pb}$ and $\mathrm{Zn}$ exceeded their background values, and the concentrations of $\mathrm{Ba}, \mathrm{Sb}$ and $\mathrm{Tl}$ in only few soil samples exceeded their regulatory limits. Those soils were highly/moderately affected in those sites with mine waste discharged on the land. The ecological risk was found to be high for $\mathrm{Cu}, \mathrm{Pb}$ and $\mathrm{Zn}$. Seven heavy metals in soil pose potential health risk $($ HRI $>1)$.

\section{Water and river sediments}

Three papers in this Special Issue refer to the second topic, water and river, sediments.

Murtaza et al. (2019) assessed As concentrations and associated health risk in the drinking water of three health facilities of Vehari District, Pakistan. Seventy-five drinking water samples were examined for As contents and for EC, $\mathrm{pH}$, total soluble salts, $\mathrm{Cl}^{-}$, $\mathrm{CO}_{3}^{=}, \mathrm{CO}_{3} \mathrm{H}^{-}, \mathrm{F}^{-}, \mathrm{NO}_{3}{ }^{-}, \mathrm{NO}_{2}{ }^{-}, \mathrm{Ca}^{++}, \mathrm{Mg}^{++}$and $\mathrm{Fe}$. It was found that $52 \%$ of drinking water samples of Vehari have As concentration greater than WHO permissible limit and $17 \%$ have concentration greater than PaK-EPA permissible limit. The risk assessment parameters (ADD, HQ and CR) showed possible carcinogenic and noncarcinogenic risks associated with ingestion of As-contaminated drinking water in the healthcare facilities. The authors concluded that hospitals and health centres in Vehari are in need of safe drinking water.

Martinez-Sanchez et al. (2019) studied the solubility and bioavailability of As in the soils of water courses that drain into the Mar Menor lagoon in southeastern Spain, using nine single chemical extractions with different reagents. The values obtained for As, Fe and $\mathrm{Mn}$ show a clear correlation. The mineralogical composition is seen to significantly influence the mobility of the studied elements and shows the relation between the soils and materials of mining origin. The high values of As extracted by the MerhaJackson method show that the particulate As that enters the Mar Menor lagoon through the water course is susceptible to mobilization when the organic matter content is high.

Zheng et al. (2019) researched spatial and temporal distribution characteristics and ecological risk assessment to heavy metals contained in sediments of the Yarlung Zangbo River on the Qinghai-Tibet Plateau. The results show that $\mathrm{Ti}, \mathrm{Mn}$ and $\mathrm{Cr}$ are the main heavy metals found in the sediments of the researched river, accounting for $51 \%, 10 \%$ and $7 \%$ of the total heavy metals, respectively. There were no significant contents over time, but there were significant spatial variations. According to the different ecological risk assessment models, it is calculated that the heavy metals in the surface sediments of the river basin have a low or no pollution risk.

\section{PAHs}

Two papers in this Special Issue are concerned with the third topic, PAHs:

Kistaubayeva et al. (2019) investigated sources' soil-air exchange direction and spatial distribution of PAH concentrations in soil phase in Istanbul, Turkey. The authors collected samples at 34 points of the urban and rural sites on the Asian and the Europe sides of Istanbul.

Average $\sum 16 \mathrm{PAH}$ concentrations were found as $22.11 \mathrm{ng} / \mathrm{g} \mathrm{dw}$ for urban site and $19.53 \mathrm{ng} / \mathrm{g} \mathrm{dw}$ for rural site, respectively. Acenaphthalene and benzo[k]fluoranthene were observed as the dominant species. Higher concentrations were found at industrial region, located to the western part and northern part of Europe Side, and SE part of the Asian side. Sources of PAHs were determined as coal combustion and use of diesel vehicles.

Minkina et al. (2019) investigated the accumulation and transformation of benzo[a]pyrene in model experiment with Haplic Chernozem under artificial contamination with increasing doses of pollutant introduced. Extraction of $\mathrm{BaP}$ from the soil was carried out by saponification method. The 
determination of $\mathrm{BaP}$ was performed by high-performance liquid chromatography with fluorescence detection. According to the content in the model experiment, PAHs formed the following descending series: $\quad$ pyrene $>$ chrysene $>$ phenanthrene $>$ fluoranthene $>$ acenaphthylene $>$ naphthalene $>$ fluorene $>$ anthracene. The degree of $\mathrm{BaP}$ destruction over 2 years research increased and ranged from 9 to $44 \%$.

\section{Biochar}

Two papers in this Special Issue dealt with the fourth topic, biochar.

Gorutsov et al. (2019) reviewed the mechanisms of biochar interactions with microorganisms in soil. This review provides an analysis of current data about the effect of biochar on the main groups of soil enzymes, the composition of the microbiota consortia and the detoxification of pollutants. Data are presented on the effect of biochar on the physicochemical properties of soils, the content of mineral nutrients and the response of microbial communities to these changes. The interaction between biochar and microorganisms during the detoxification of heavy metals and degradation of PAH is discussed.

Hussain et al. (2019) evaluated the potential of acid and base activated biochar from cotton stalks (CSB) for $\mathrm{As}(\mathrm{v})$ removal from contaminated water. The CSB was treated with $0.5 \mathrm{M} \mathrm{KOH}(\mathrm{BCSB})$ and $\mathrm{H}_{3} \mathrm{PO}_{4}$ (ACSB) separately to change its surface properties. The CSB, ACSB and BCSB were characterized using BET, FTIR and SEM analyses to check the effectiveness and insight of the mechanisms involved in the removal of As. The experimental adsorption results were better explained with Freundlich and pseudosecond kinetic models as compared with other equilibrium and kinetic models. The authors concluded that activation of CSB with base can be used effectively $(4.48 \mathrm{mg} / \mathrm{g})$ in an environmental-friendly manner to remove As from contaminated aqueous systems.

\section{Microbial activity}

Two papers in this Special Issue refer to the fifth topic, microbial activity.

Hamidpour et al. (2019) investigated the combined effects of EDTA and plant growth-promoting rhizobacteria (PGPR) on the phytoextraction of $\mathrm{Cd}$, $\mathrm{Pb}$ and $\mathrm{Cd}$ by corn and chemical fractionation of these elements in a calcareous-contaminated soil. Results indicated that the phytoextraction efficiency of EDTA could be enhanced by application of PGPRs. EDTA alone increased metal contents of corn roots and shoots compared to the untreated soil; however, the enhancement was higher when EDTA and PGPRs were applied together. Moreover, bacterial inoculation could improve the efficiency of EDTA in phytoextraction of heavy metals from multimetal-contaminated soils. However, a long-term field study is necessary to verify the efficacy of this treatment.

Anagnostopoulos et al. (2019) researched the effect of bicarbonate ions present in the aqueous phase on $\mathrm{Ca}$-autunite dissolution under anaerobic conditions, as well as the role of metal-reducing facultative bacterium Shewanella oneidensis MR1. This research was made as a feasible remediation strategy for sequestering uranium in situ in contaminated groundwater at the Hanford Site (Washington, USA). The remediation consisted in the introduction of Na-tripolyphosphate into uranium-bearing porous que conduce a la formación of uranyl phosphate minerals (autunite). But the stability of these minerals can be affected by the presence of bicarbonate and bacterial activity, therefore these factors should be considered for designing robust long-term remediation strategies.

\section{Urban soils}

Two papers in this Special Issue refer to the sixth topic, urban soils.

Tume et al. (2019) executed an environmental assessment of a systematic survey of urban and rural soils of the Quintero and Puchuncavi districts in Chile. Cluster and principal component analysis indicated that the potentially harmful elements (PHE) were divided into main groups, which could control geogenic ( $\mathrm{Ni}, \mathrm{V}$ and $\mathrm{Zn}$ ) and anthropogenic (As, $\mathrm{Cd}$, $\mathrm{Cu}$ and $\mathrm{Pb}$ ) factors. The spatial distribution of $\mathrm{As}, \mathrm{Cd}$, $\mathrm{Cu}$ and $\mathrm{Pb}$ presents a spatial pattern around the Puchuncavi-Ventanas industrial park. Contamination factor index reported considerable contamination to very high contamination in some soils. Hazard quotient values were higher for children than for adults, while the cancer risk index values were in acceptable range. 
Reyes et al. (2019) researched multielement geochemistry and source patterns of potentially toxic elements (PTEs) in soils of the Taltal urban area (Northern Chile) following a workflow of robust data analysis based on the new Robust Compositional Contamination Index (RCCI). Follow-up (fractal/multifractal technique applied to GIS model) studies of $\mathrm{As}, \mathrm{Cd}, \mathrm{Cr}, \mathrm{Cu}, \mathrm{Pb}$ and $\mathrm{Zn}$ have allowed displaying spatial distribution of these PTEs. Cr was associated with pedogenic processes of sorption and coprecipitation in marine deposits. Low baseline values of PTEs were found in most of the survey area, and high values were often very small in extent, except for some sites with abandoned mining waste deposits in the northwestern part of the Taltal city.

\section{Endemic diseases}

One paper refers to the seventh and last topic, endemic diseases.

Korobova et al. (2019) presented a new approach to the study of endemic diseases of geochemical origin and methodological approaches towards their prevention and elimination. The authors distinguished two genetically different types of endemic diseases, each having a specifically spatial structure: (1) diseases of natural origin due to element natural deficiency or excess in the particular zones or areas; (2) diseases of anthropogenic origin related to chemical transformation of the environment in the course of agricultural or industrial production. The second ones present health risk and can be mapped as a genetically two-layer structure, characterizing deviation of the existing geochemical conditions for those ideal for specific specie. The hypothesis is tested on example of thyroid diseases in iodine-deficient areas affected by a nuclear accident with ${ }^{131}$ I fallout.

\section{Conclusions}

The subject of this Special Issue is of great importance, and the 20 papers cover significant aspects of fundamental theoretical and applied research in soil contamination and human health and provide advances to the existing knowledge.

Acknowledgements I would firstly like to thank the Co-Guest Editors, Prof. Dr. Elena Korobova (Vernadsky Institute of
Geochemistry and Analytical Chemistry, Moscow, Russian Federation), Prof. Dr. V. V. Ermakov (Vernadsky Institute of Geochemistry and Analytical Chemistry, Moscow, Russian Federation), Prof. Dr. Carmen Pérez-Sirvent (Faculty of Chemistry, University of Murcia, Spain), Prof. Dr. Michael J. Watts (School of Biosciences, University of Nottingham) for their valuable collaboration. Moreover, I would like to thank the authors for their contributions and for their patience with the review process as well as the reviewers for their observations. Their efforts have improved the quality of this Special Issue. Help with English from James Dove and IT assistance from Oriol Bech are also greatly appreciated. I am extremely grateful to Prof. Dr. Ming Hung Wong, Editor-in-Chief of EGAH, Ms. Sherine Joseph, Handling Editor, and Crystal Lin Siyi, Assistant to Prof. MH Wong; without their knowledge and experience, this Special Issue could never have been published.

\section{References}

Anagnostopoulos, V., Katsenovich, Y., Lee, B., \& Lee, H. M. (2019). Biotic dissolution of autunite under anaerobic conditions: effect of bicarbonates and Shewanella oneidensis MR1 microbial activity. This Special Issue.

Antisari, L. V., Bini, C., Ferronato, C., Gherardi, M., \& Vianello, G. (2019). Translocation of potential toxic elements from soil to black cabbage (Brassica oleracea L.) growing in an abandoned mining district area of the Apuan Alps. This Special Issue.

Armienta Hernández, M. A. (2019). Heavy metals assimilation in maize (Zea mays L.) plants growing near mine tailings. This Special Issue.

Carvalho, L. C., Vieira, C., Abreu, M. M., \& Magalhaes, M. C. F. (2019). Physiological response of Cistus salviifolius L. to high arsenic concentrations. This Special Issue.

Dbaibo, R., Bashour, I., Hamadeh, S., \& Toufeili, I. (2019). Uptake of $\mathrm{Cd}, \mathrm{Pb}$ and $\mathrm{Ni}$ by Origanum syriacum produced in Lebanon. This Special Issue.

Gorovtsov, A.V., Minkina, T.M., Mandzhieva, S.S., Perelomov, L.V., Soja, G., Zamulina, I.V., Rajput, V., Sushkova, S.N., Mohan, D., \& Yao, J. (2019). The mechanisms of biochar interactions with microorganisms in soil. This Special Issue.

Hamidpour, M., Nemati, H., Dahaji, P. A., \& Roosta, H. R. (2019). Effects of plant growth-promoting bacteria on EDTA-assisted phytoextraction of heavy metals in a contaminated calcareous soil. This Special Issue.

Hussain, M., Imran, M., Abbas, G., Shahid, M., Iqbal, M., Naeem, M. A., Murtaza, B., Amjad, M., Shah, N. S., Khan, Z. U. H., \& Islam, A. U. (2019). A new biochar from cotton stalks for As (V) removal from aqueous solutions: Its improvement with $\mathrm{H}_{3} \mathrm{PO}_{4}$ and $\mathrm{KOH}$. This Special Issue.

Kistaubayeva, A., Kuzu, S.L., Akyüz,E., \& Saral, A. (2019). Investigation of Geospatial Distribution of PAH Compounds in Soil Phase and Determination of Soil-Air Exchange Direction in a Megacity. This Special Issue.

Korobova, E., Romanov, S., \& Silenok, A. (2019). Endemic diseases of geochemical origin and methodological approaches towards their prevention and elimination. This Special Issue. 
Martinez-Sánchez, M. J., Martinez-López, S., Gómez-Martinez, M. C., \& Pérez-Sirvent, M. C. (2019). Analysis of miningderived Arsenic inputs in a lagoon system. This special Issue.

Minkina, T., Sushkova, S., Yadav, B. K., Mandzhieva, S., Nazarenko, O. (2019). Accumulation and transformation of benzo a pyrene in Haplic Chernozem under artificial contamination. This Special Issue.

Monaci, F., Trigueros, D., Mingorance, M. D., Rossini-Oliva, S. (2019). Phytostabilization potential of Erica australis L. and Nerium oleander L.: A comparative study in the Riotinto mining area (SW Spain). This Special Issue.

Murtaza, B., Natasha, N., Amjad, M., Shahid, M., Imran, M., Shah, N.S., Abbas, G., Naeem, A., \& Amjad, M. (2019). Arsenic health risk assessment and multivariate comparison of physicochemical properties of drinking water from health facilities of District Vehari, Pakistan. This Special Issue.

Nguyen, T.P., Ruppert, H., Pasold, T., \& Sauer, B. (2019). Paddy soil geochemistry, uptake of trace elements by rice grains (Oryza sativa) and resulting health risks in the Mekong River Delta, Vietnam. This Special Issue.

Pace, R., Liberati, D., Sconocchia, P., \& De Angelis, P. (2019). Lead transfer into the vegetation layer growing naturally in a $\mathrm{Pb}$ contaminated site. This Special Issue.

Praveen, A., \& Pandey, V. C. (2019). Pteridophytes in phytoremediation. This Special Issue.
Reyes, A., Thiombane, M., Panico, A., Daniele, L., Lima, A., Di Bonito, M., \& De Vivo, B. (2019). Source patterns of Potentially Toxic Elements (PTEs) and mining activity contamination level in soils of Taltal city (Northern Chile). This Special Issue.

Suwatvitayakorn, P., Ko, M-S., Kim, K-W., \& Chanpiwat, P. (2019). Human health risk assessment of cadmium exposure through rice consumption in cadmium contamination areas of Mae Tao sub-district, Tak, Thailand. This Special Issue.

Tume, P., Barrueto, K., Olguin, M., Torres, J., Cifuentes, J., Ferraro, F.X., Roca, N., Bech, J., \& Cornejo, O. (2019). The influence of the industrial área on the pollution outside its borders: a case study from Quintero and puchuncavi districts, Chile. This Special Issue.

Zheng, L., Hulin, Ch., Qingquin, L., Can, Y., \& Xiang, H. (2019). Study on spatial and temporal distribution characteristics and ecological risk assessment to heavy metals contained in sediments of the Yarlung Zangbo river. This Special Issue.

Publisher's Note Springer Nature remains neutral with regard to jurisdictional claims in published maps and institutional affiliations. 